\title{
Early Monsoon Time Local Flow Characteristics over the Hetauda Valley and its Implications
}

\author{
S. Acharya, S. Neupane, R. Shrestha, C. Chapagain, P. Acharya, S. Maharjan \& R. Regmi \\ National Atmospheric Resource and Environmental Research Laboratory (NARERL) \\ Central Department of Physics, Tribhuvan University, Kirtipur, Kathmandu, Nepal. \\ Email:regmi_rp@hotmail.com
}

\begin{abstract}
The early monsoon time atmospheric transport processes over the Hetauda valley, the closest low-land that accommodates the third largest industrial district of Nepal, has been studied with the application of Weather Research and Forecasting (WRF) Modeling System initialized with NCEP meteorological and USGS terrain elevation and land-use data. The study reveals that the mixing layer over the Hetauda valley may evolve as much as $3 \mathrm{~km}$ above the surface during the afternoon time. The near surface atmosphere of the valley appears very weakly stratified even in the early morning time indicating that prevailing meteorology over the valley favors efficient dispersion of air pollutants. The study also reveals that the daytime upslope winds over the Hetauda valley and associated northern mountains effectively intrude into the Kathmandu valley enhancing the southwesterly and northwesterly wind system of the valley. Intrusion of local flows appears to be accompanied with the excitation of mountain waves and plain-to-plateau wind. Formation of lowlevel rotors over the Hetauda valley, excitation of mountain waves and the strong downdrafts over the southwestern part of the Kathmandu valley may put aircrafts into high risk. The pattern of local flow fields strongly suggest that the increase emissions over the Hetauda valley can have significant help to further deteriorate the already unhealthy air of Kathmandu.
\end{abstract}

Keywords: Numerical simulation, Hetauda, mountain-plain wind system, atmospheric transport.

\section{INTRODUCTION}

The Hetauda valley is located in the southern plain of central development region of Nepal and just $40 \mathrm{~km}$ southwest form Kathmandu valley. The valley is situated in a unique geographical structured of valley like shape called doon surrounded by the Mahabharata Mountain Range in the north and the Siwalik Hill Range in the south. The rivers Rapti, Samari and Karra run through the valley and flows southwest to merge in the Narayani River. Traverse through by the national highways, proximity to the capital and the Indian urban centers and existence of the many entry and exit points leading in and out of this valley, Hetauda is just set to grow into a commercial powerhouse of Nepal.

The valley accommodates a municipality of population of about 90 thousand in 20 thousand households. Nepal's third largest industrial district and the largest cement factory, the Hetauda Cement Factory, are also located within the municipal area of about 47.77 sq. $\mathrm{km}$. In recent years, the valley has seen haphazard urbanization and uncoordinated industrial expansions. As a result, serious degradation in the quality of air, water and soil are currently underway.

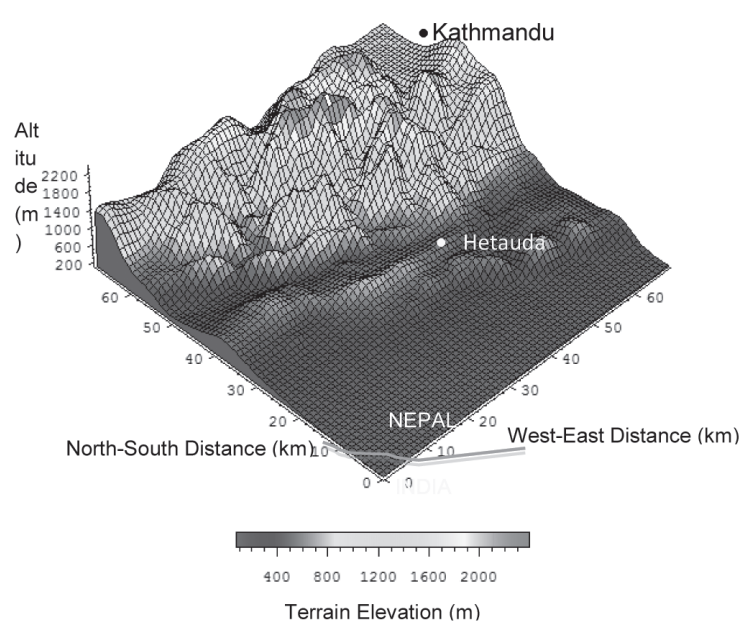

Fig. 1. 3-D topographical image of Hetauda valley and its surrounding areas. Kathmandu valley can be seen in the top-right corner of the figure.

As the Kathmandu valley is in close proximity and downwind of upvalley wind from Hetauda, the increased emission activities over the Hetuda valley can be expected to intrude into the Kathmandu valley further worsening the already unhealthy air of Kathmandu. 
Thus, in this paper, we will discuss the early monsoon regional scale local flow patterns and their implications for air pollution dispersion over the Hetauda valley and its transport up into the Kathmandu valley.

\section{MATERIALS AND METHODS}

The characteristic patterns of meteorological flows over the Hetauda valley and its surroundings have been numerically simulated using the Weather Research and Forecasting (WRF) Modeling System (Skamarock et al. 2005). Based on the past simulation experiences over different parts of the Himalayan complex terrain (e.g., Regmi \& Maharjan, 2013; Regmi, 2012; Regmi et al. 2003), we have applied a triply nested two-way interacting domain system.

The model was initialized with NCEP 6-hourly meteorological data with a resolution of $1.0^{\circ} \times 1.0^{\circ}$. The simulation was carried out for the period of 15 May 0000 UTC to 19 May 0000 UTC, 2013. The land use of 24 categories and 30-second terrain elevation data by United States Geological Survey (USGS) has been used in the calculation. The coarse and the find domain include 51 $\times 51 \times 34$ grid points, and horizontal grid size is 9 and 3 $\mathrm{km}$, respectively, whereas the finest domain include $70 \mathrm{x}$ $70 \times 34$ grid points with horizontal grid size $1 \mathrm{~km}$. The area coverage and terrain structure of the finest domain is shown in Fig. 1. The centers of all the three domains were placed at the center of the Hetauda Municipality. The planetary boundary layer (PBL), and surface layer schemes and the NOAH land surface model (LSM), along with the Dudhia short wave, RRTM long-wave radiation parameterizations for all the domains but the parameterization of schemes of Lin et al. as well as the Kain-Fritsch convective parameterization scheme was used only in the largest domain.

\section{RESULTS}

During the simulation period beyond the spinup time (the first 24 hours of model calculation), almost the same diurnal variations of local flows were predicted. However, the day of 16 May, 2013 appeared to be rather distinct in the sense that the Hetauda valley experienced a rather stormy westerly wind in the afternoon time that vigorously intruded into the Kathmandu valley against the general tendency of gentle intrusions in other normal days. Thus, we primarily discuss the diurnal variation of wind patterns over the Hetauda valley and its intrusion into the Kathmandu valley as predicted for the day of 16 May 2013.

\section{NEAR SURFACE WIND PATTERNS}

In this subsection, we will describe the diurnal pattern of near surface local flows over the Hetauda valley as predicted by the model. Fig. 2 shows the diurnal distribution of local flows at about 30 meters height above the ground level. It can be seen that the valley experiences several types of wind fields in different parts during the late night and early morning times (Fig. 2a, j). The central, western and southern parts of the valley witness rather southeasterly wind whereas the northern part of the valley largely receives the downslope wind from the northern mountain ranges. The downslope winds shooting over the Hetauda valley from the eastern and western parts may cross beyond Nepal keeping the southeasterly gentle flows over the central area of the valley. As the morning progresses (see Figs 2b, c), significant changes can be observed in the northern, western and eastern parts of the valley but the flow pattern in the central and southern parts of the valley essentially appear the same. The strong downslope winds over the northern mountain slopes vanish in the early morning (Fig. 2b) and after sunrise (Fig. 2c), these mountain slopes develop upslope winds. The wind over the central area weakens; the eastern area might become windless but the southern little hilly area and beyond there still prevails relatively strong winds. In the late morning (Fig. 2d), the whole valley area receives southerly and the upslope winds over the Hetauda valley and the northern mountain ranges are connected with the northwesterly and southwesterly wind systems of the Kathmandu valley and continue to feed wind into the Kathmandu valley until the early evening (see Figs. 2dh).

In the late afternoon, strong subsidence might occur over the eastern and southeastern part of the valley (see diverging wind vectors in the left central and lower part of the domain in Fig $2 \mathrm{~g}, \mathrm{~h}$ ) causing storm like flow. Such flow pattern can have significant enhancement in the intrusion of the local flow in the Kathmandu valley, which can bring low-land pollutants directly up into Kathmandu valley. Such occasional intrusion of storm like flow over the Kathmandu valley and over the southern low-land may also sweep out the accumulated dust and or pollutants over the Kathmandu valley and over the Hetauda valley towards corresponding eastern regions (see Figs. 2i-k).

In the evening the Hetauda valley appears to return gradually into the flow pattern described earlier for night and early morning time. It is interesting to note that Hetauda valley generally experiences gentle winds and rarely remains windless. It generally experiences southeasterly wind except during the situations when subsidence occurs in the western neighboring areas of the valley. 
S. Acharya, S. Neupane, R. Shrestha, C. Chapagain, P. Acharya, S. Maharjan \& R. Regmi

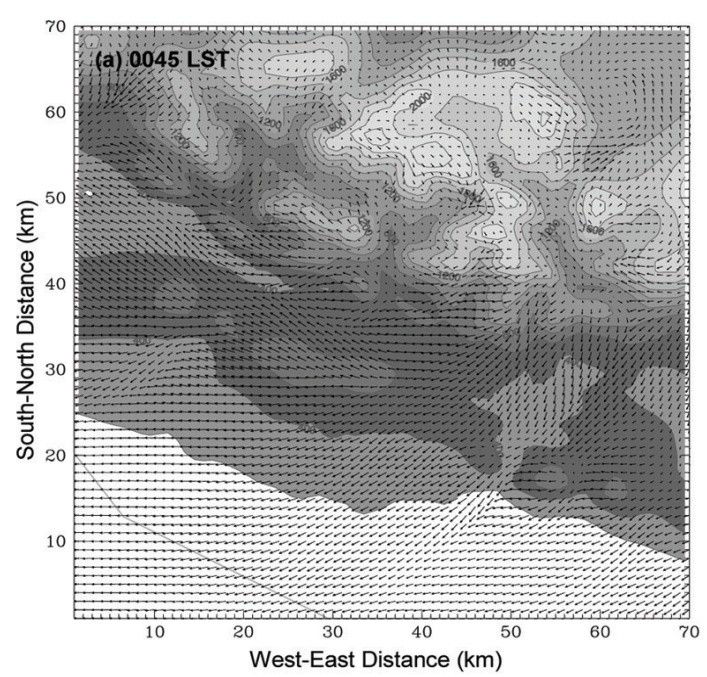

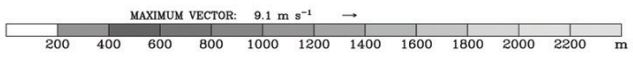

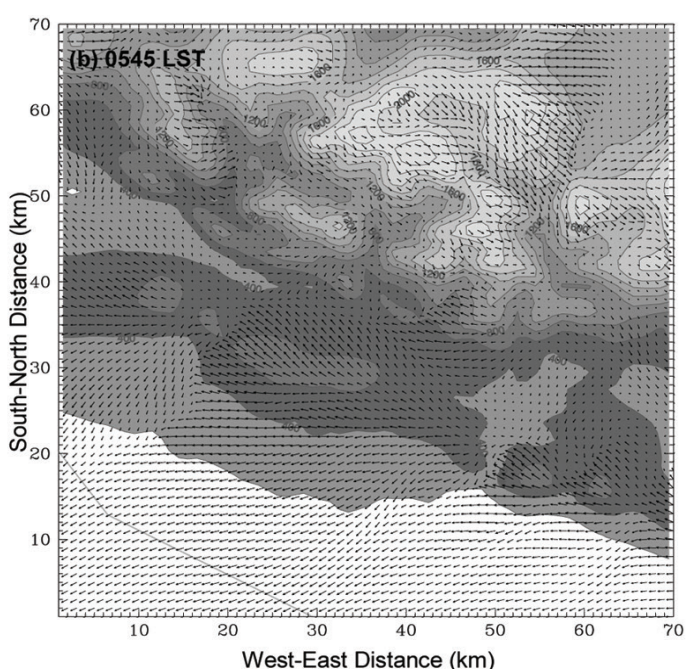

West-East Distance $(\mathrm{km})$

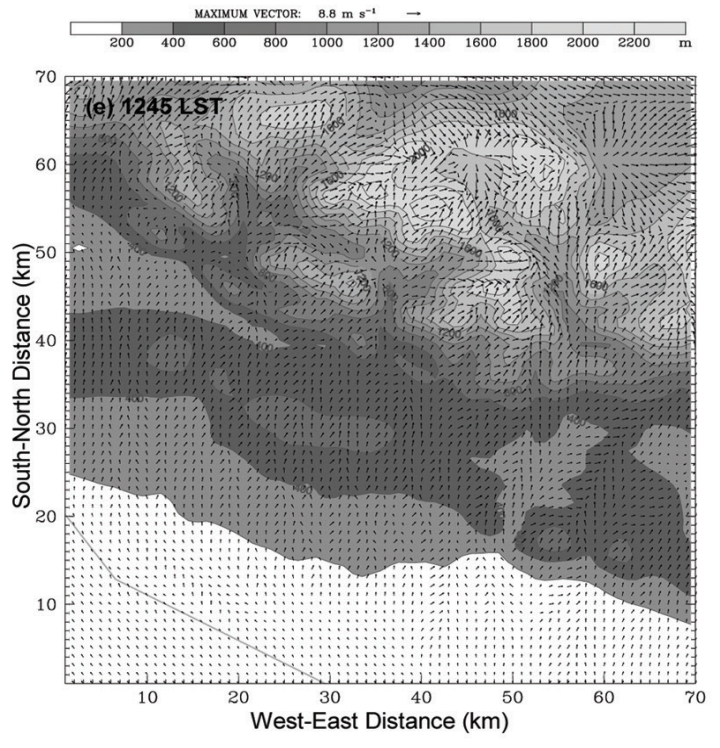

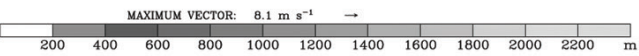

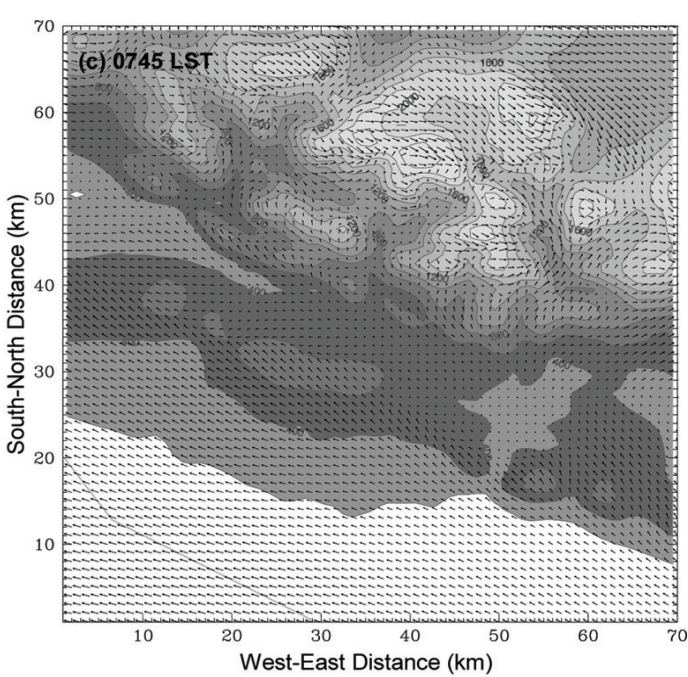

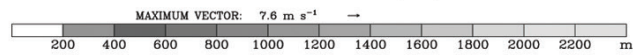

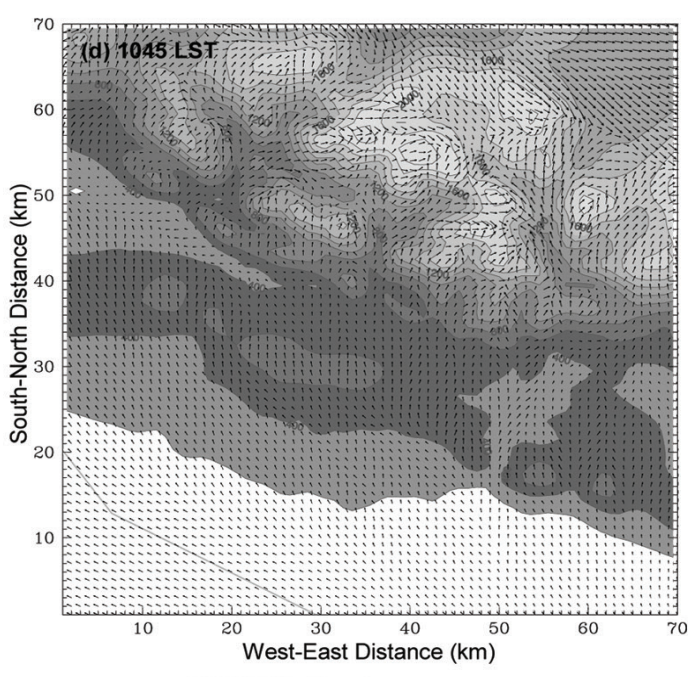

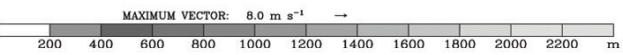

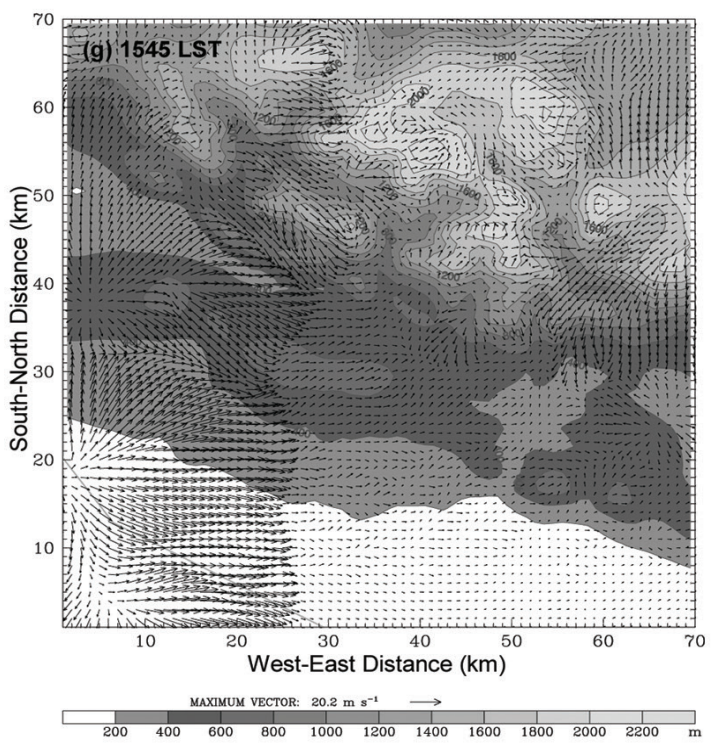



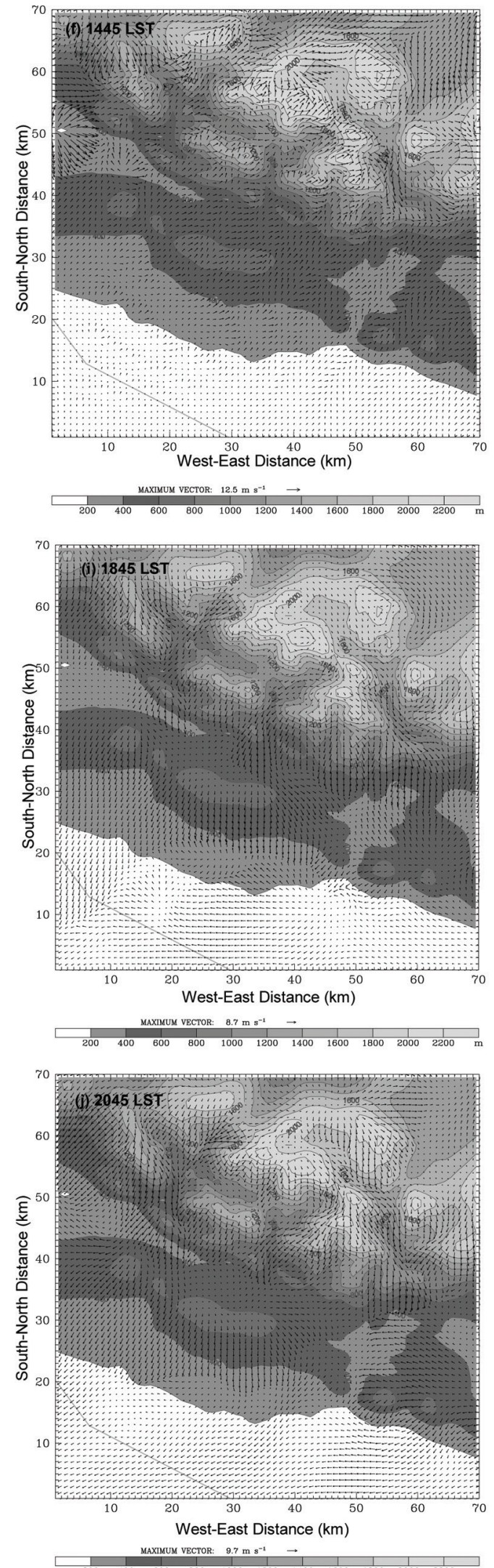
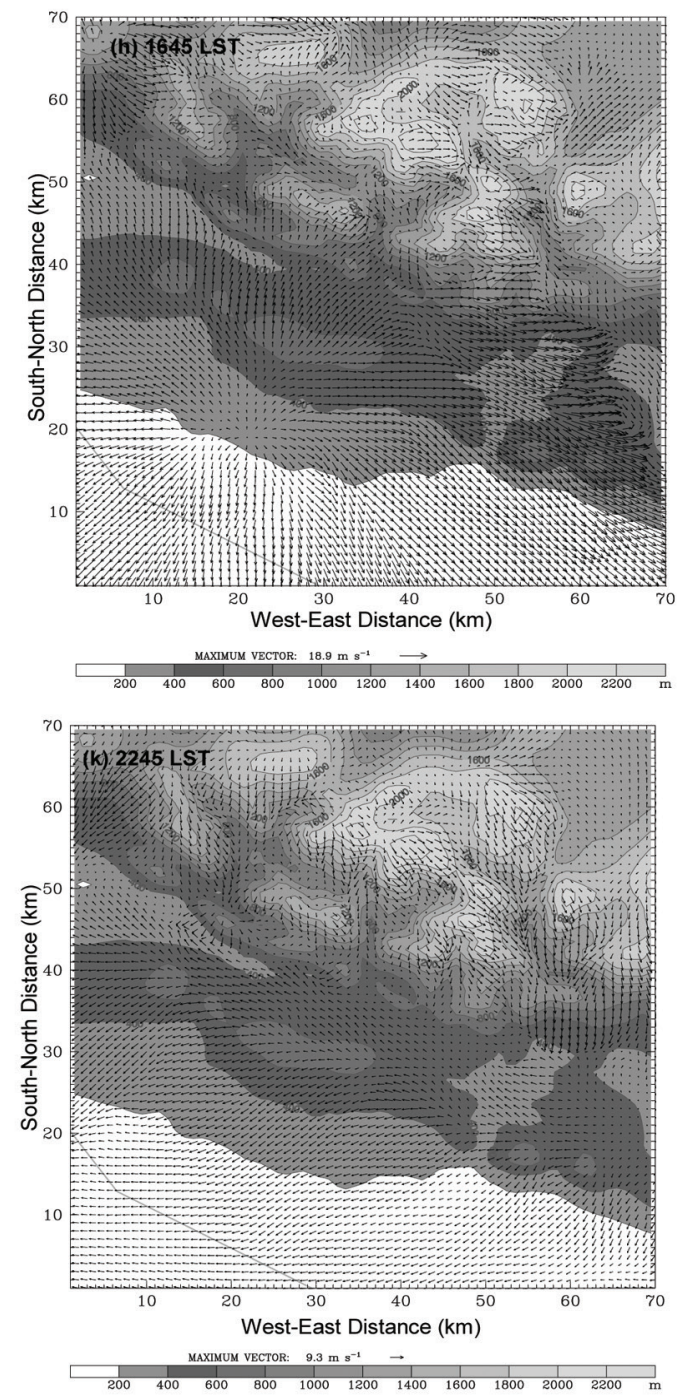

Fig. 2. Diurnal distribution of near surface wind over the Hetauda valley and its surroundings.

\section{Vertical Distribution of Flow Fields}

Fig. 3 shows the diurnal variation of the vertical structure of the horizontal wind vectors, vertical wind speed and the potential temperature contours distribution along the west-east line passing through the center of the Hetauda Municipality. As can be seen from the figures (see Figs. 3a-c, and k) Hetauda valley may experiences easterly wind of about $500 \mathrm{~m}$ deep close to the surface capped by the strong westerly wind aloft during the late night until late morning. Very intense wind shear appears over the valley during the same period. Simulated wind system also shows that after sunrise the easterly wind close to the surface weakens significantly (Fig. 3c) soon the mixing activities commence over the valley. In the late morning, the mixed layer height over the valley may develop up to 1500 meters above the ground, which further increases to 
attain about 2500 meters high in the afternoon (see Figs. 3d-f).

As the westerly wind, possibly, due to subsidence in the western area penetrates into the Hetauda valley, the

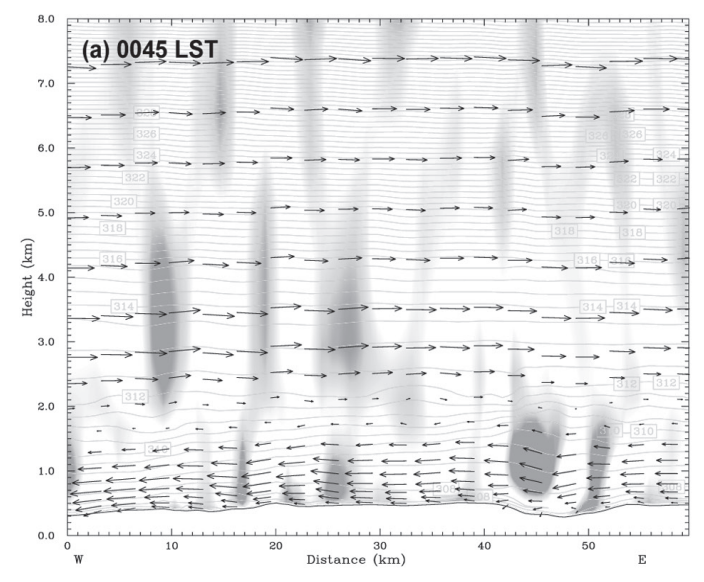

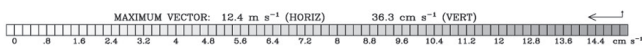

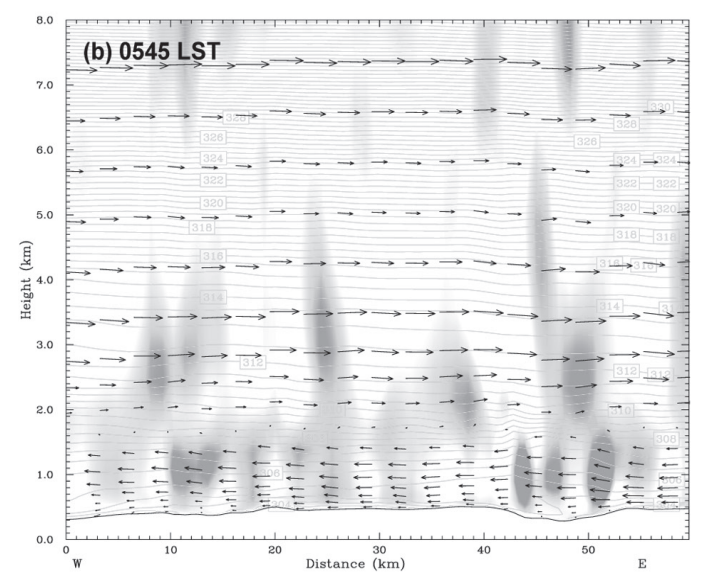

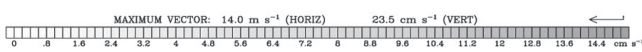

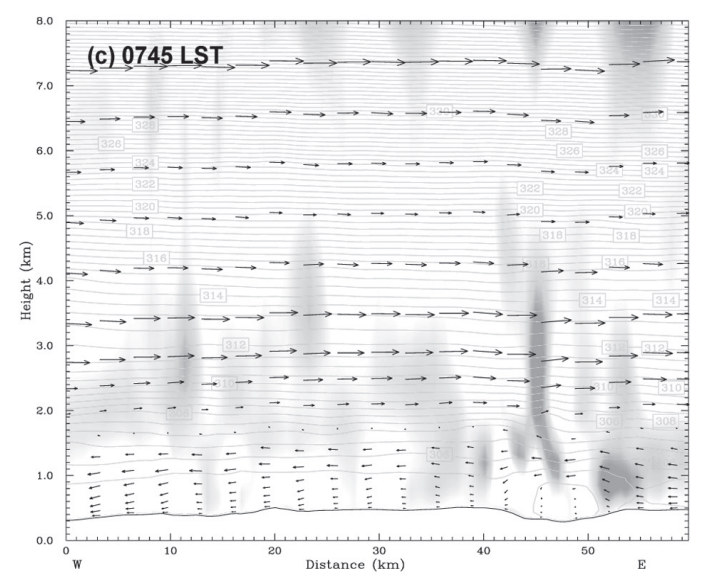

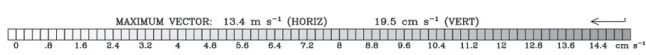

mixed layer activities is highly suppressed and the near surface atmosphere over the valley gets stratified (see wind vectors with dense potential temperature contours penetrating from the left in Fig. 3g) generating strong vertical flow at the central area of the valley.

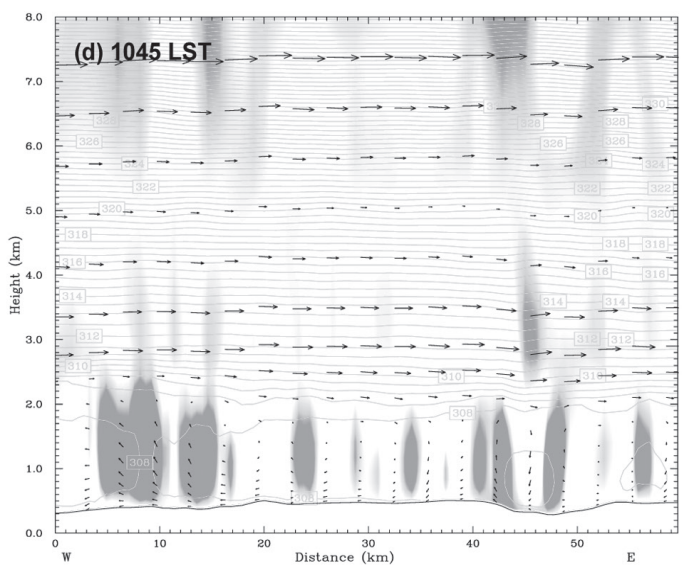

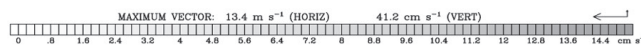

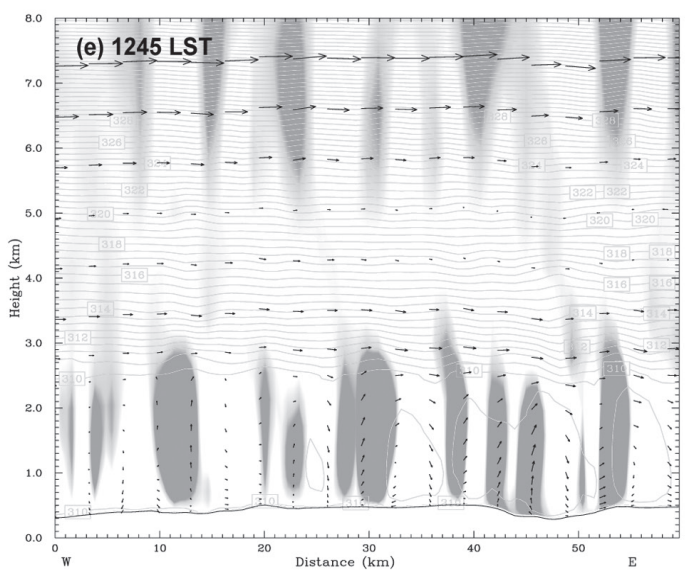

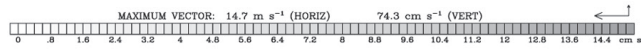

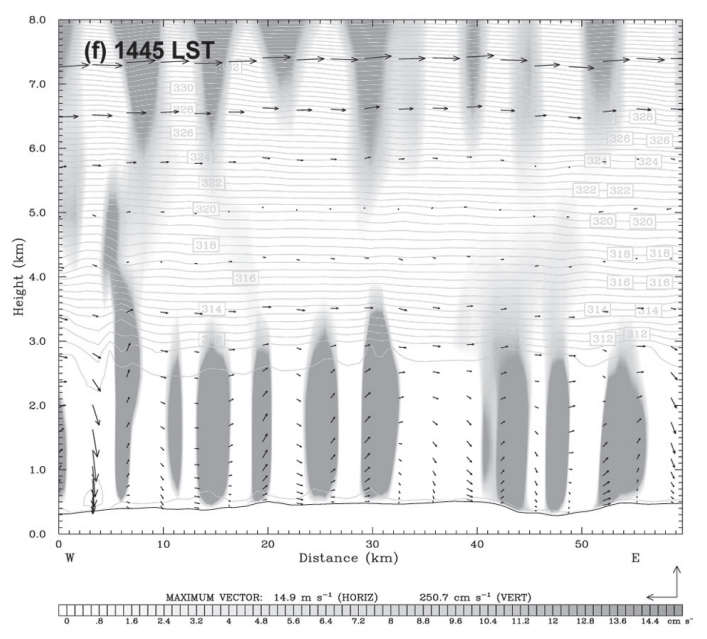




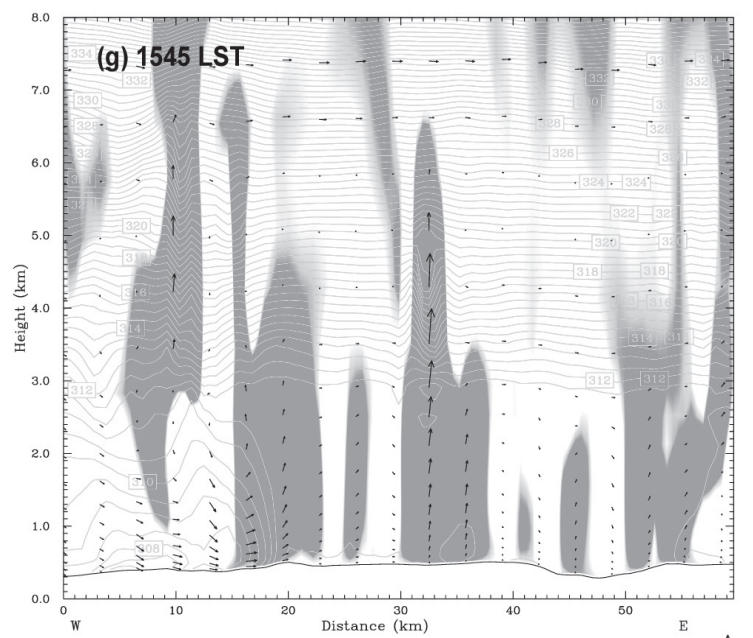

प1ШUس

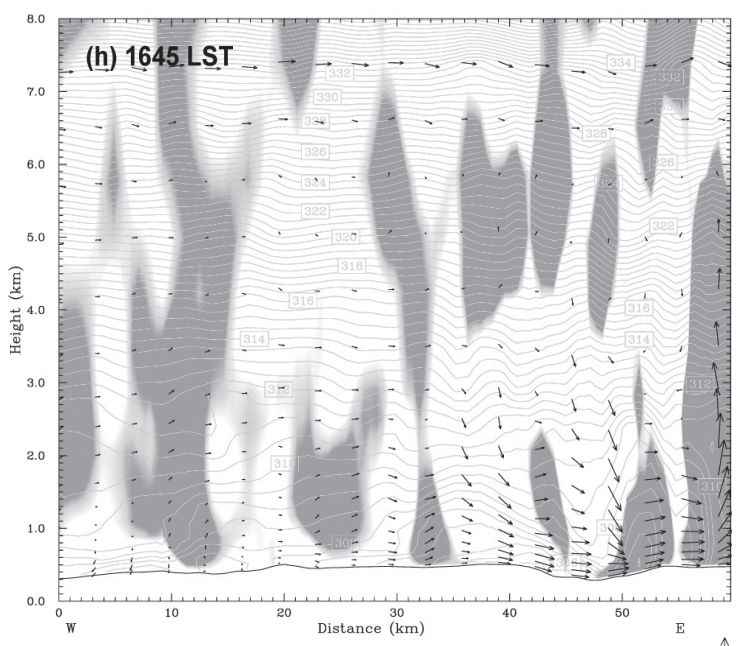

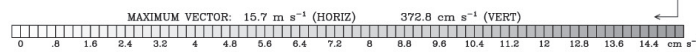

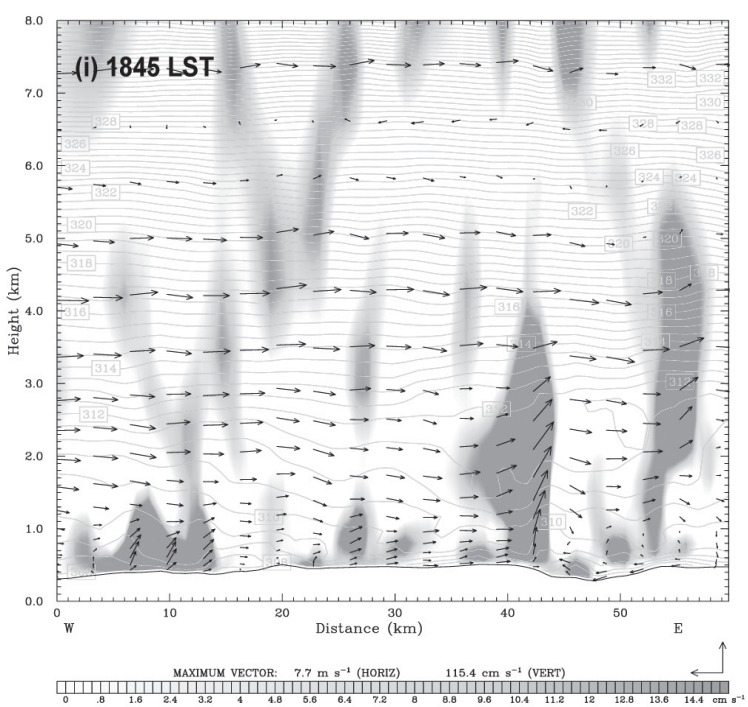

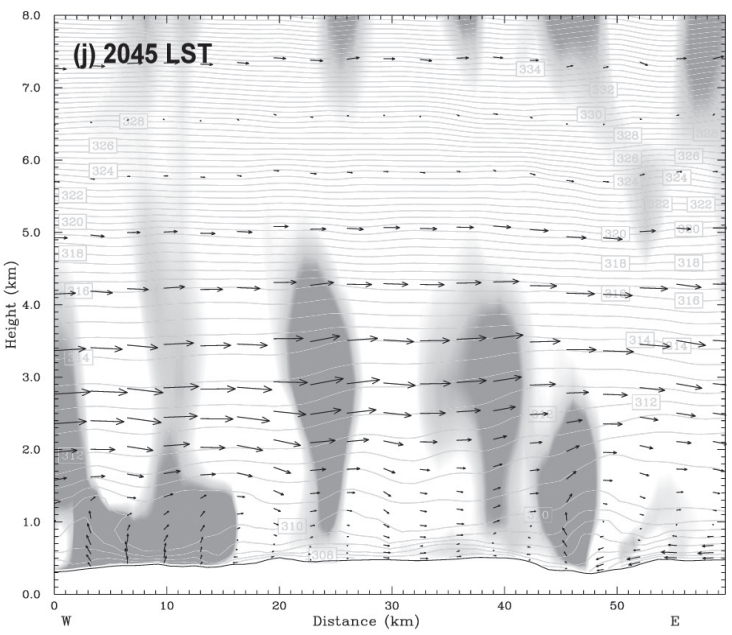

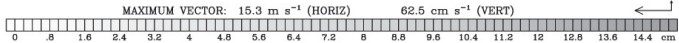

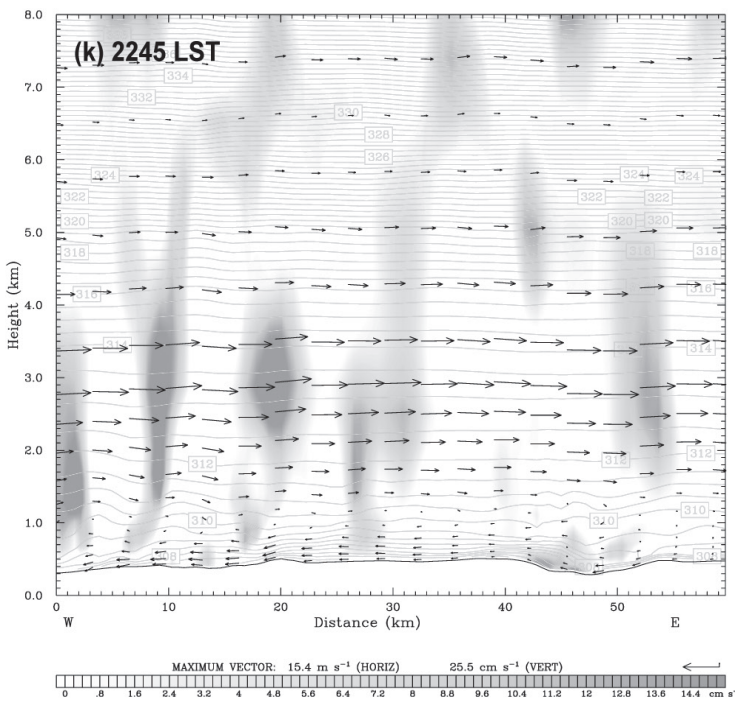

Fig. 3. Cross-sectional distribution of potential temperature, horizontal and vertical winds along the line A-B on 16 May 2012.

Soon the western flow passes through the valley, the mixed layer developed in the afternoon vanishes and strong subsidence might occur in the eastern area (Fig. $3 \mathrm{~h}$ ). This flow may execute the nature of hydraulic jump. After the passage of this supercritical flows, the valley may experience a deep westerly flow in between late afternoon to early evening but from late evening the valley again starts to resume the double layering flow pattern (Fig. 3i-k) as described earlier. It is interesting to note that there is strong diurnal periodicity of mixed layer development and wind pattern over the Hetauda valley except for the abnormal weather days.

Similar study over the Chitwan valley (Regmi, 2012), neighboring western valley, also show the strong 
subsidence in the afternoon time. Although, it cannot be overly stressed because both the studies are of shortterm in nature, the coincidence of strong subsidence apparent in both the studies suggests that this part of the country is subsidence prone and is predisposed to high meteorological hazards for aviation activities. As subsidence can also bring down regional pollutants propagating in the upper layer of the atmosphere, regional pollutants might have also contributed in deteriorating the ambient air quality of the area as well.

\section{Air Pollutants Transport up into the Kathmandu Valley}

Fig. 4 shows the cross-sectional plot of horizontal (vector) and vertical (raster) distribution of wind and the potential temperature contours along the southwest-northeast line passing through the center of the Hetauda Municipality. It can bee seen that during the mid night until early morning time (Fig. 4a) the wind system over the Kathmandu and the Hetauda is apparently decoupled whereas the wind system of both the valleys are closely connected during the rest of the time. In the early morning, the Kathmandu valley may develop strong updraft over the southwestern part of it (Fig.4b) and after sunrise the same part may
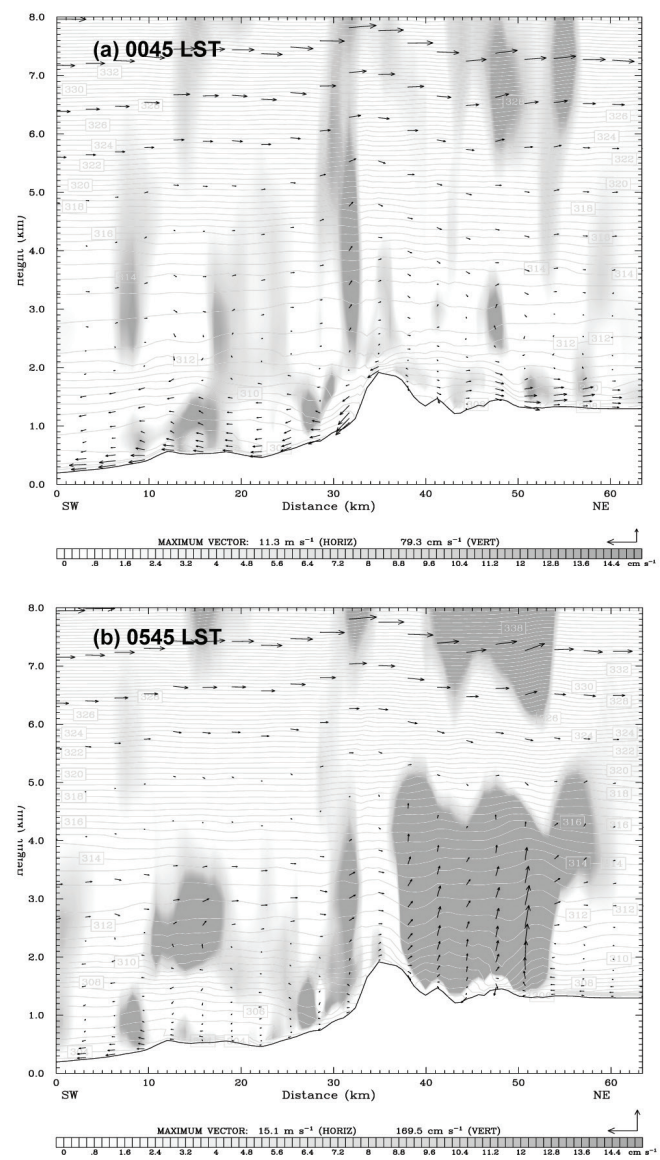

receive a weak subsidence (Fig.4c). In the late morning (Fig. 4d), the mixed layer over the Hetauda valley may develop up to the height of the southwestern mountain of the Kathmandu valley and may start to feed valley winds along with the subsidence. By the noontime, the combination of upvalley and plane-to-plateau wind from and over the Hetauda valley deeply and vigorously penetrates the Kathmandu valley and enhances further during the afternoon time only to vanish in the early evening (see Figs. 4e-i).

It is important to note that intrusion of upvalley and plane-to-plateau wind into the Kathmandu valley is accompanied with the intensive mountain waves (see wavy potential temperature contours in Figs. 4d-i) and rotor formation over the Hetauda valley (Figs $4 \mathrm{~g}$ and $\mathrm{i}$ ). Such wavy circulation and formation of rotor as well as the downdrafts offers very high risks for aviation activities, particularly, the small aircrafts are highly vulnerable to such meteorological flow regimes. A long-term study is necessary to examine if such phenomena are regular or occasional as well as to assess the flight risks related to mountain waves, turbulence and downdrafts apparent in this study.
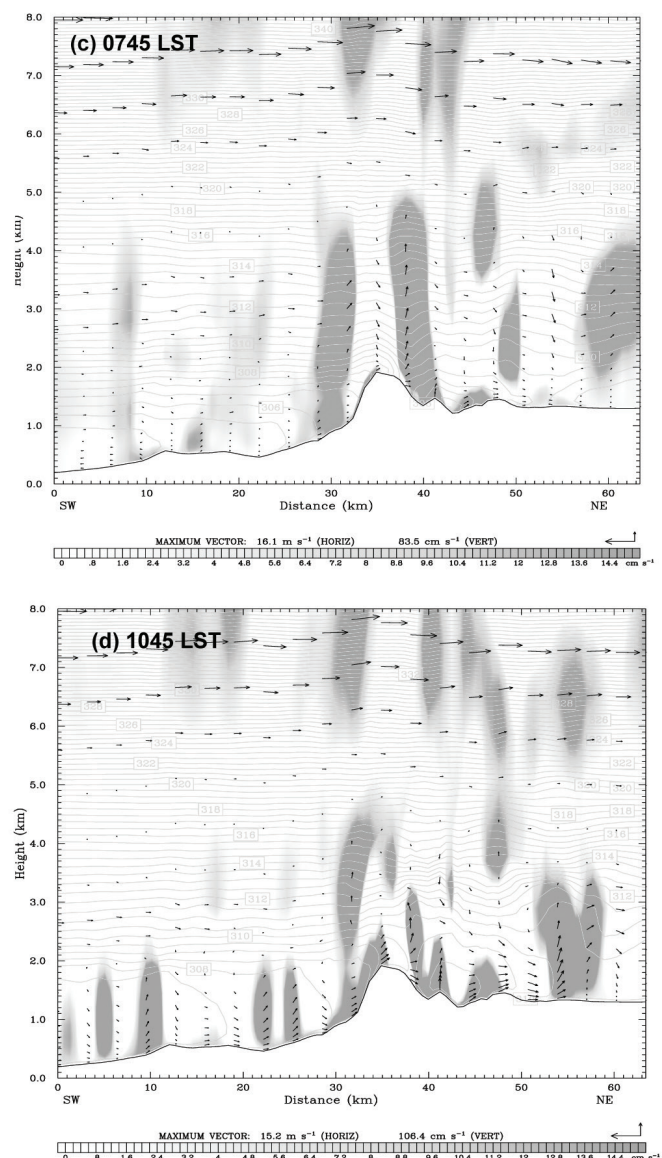


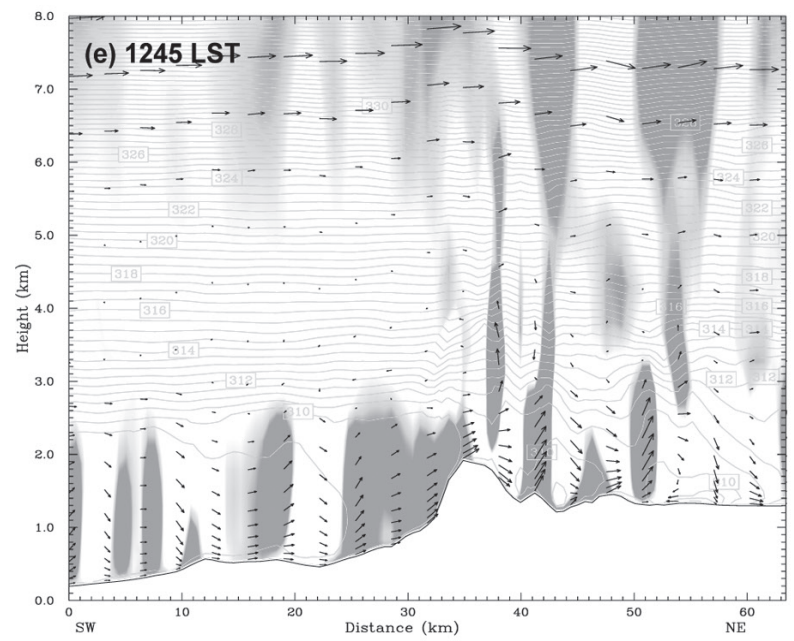

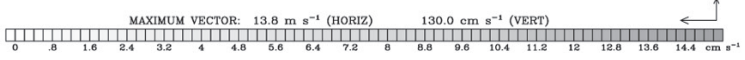

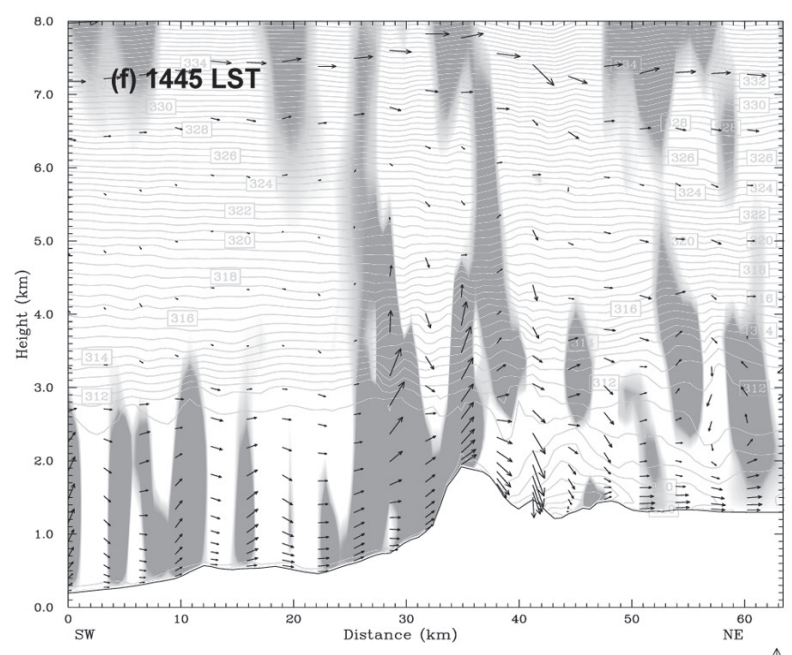

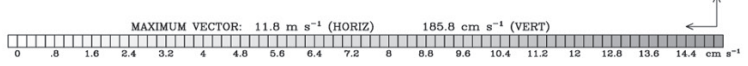

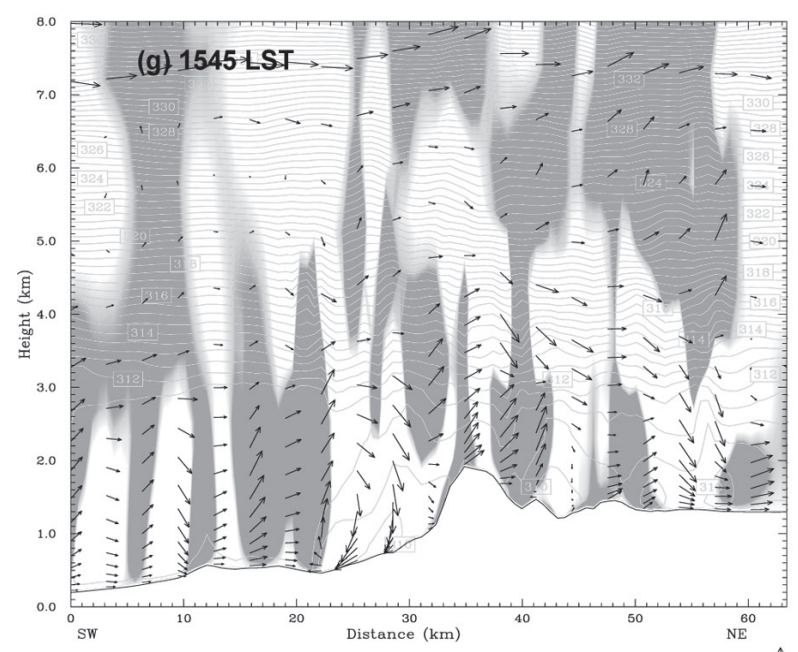

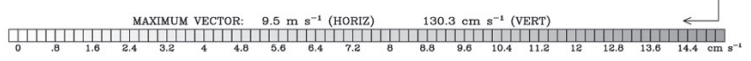

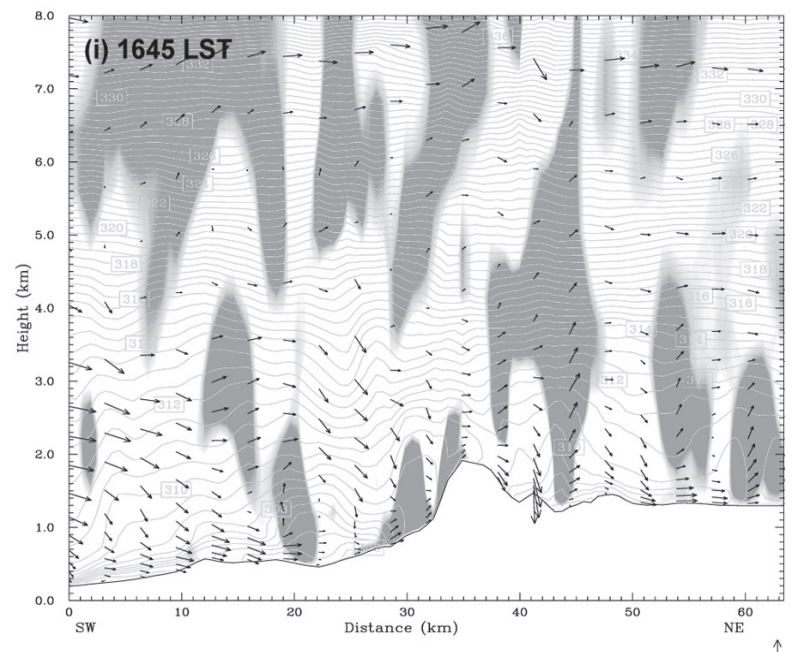

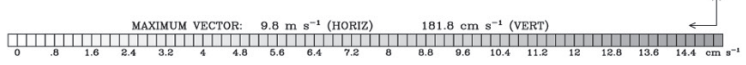

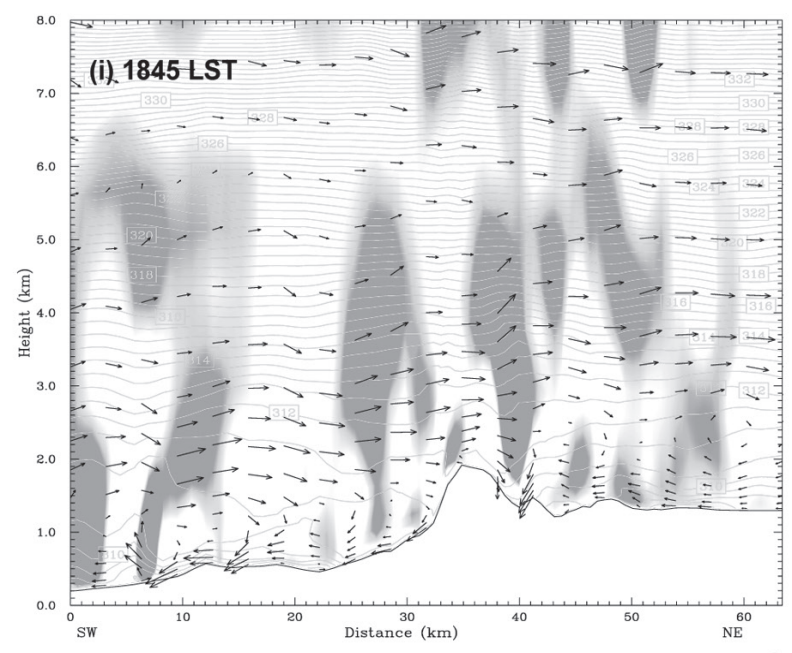

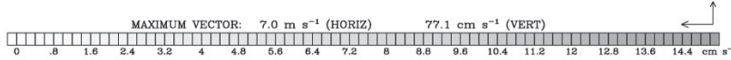

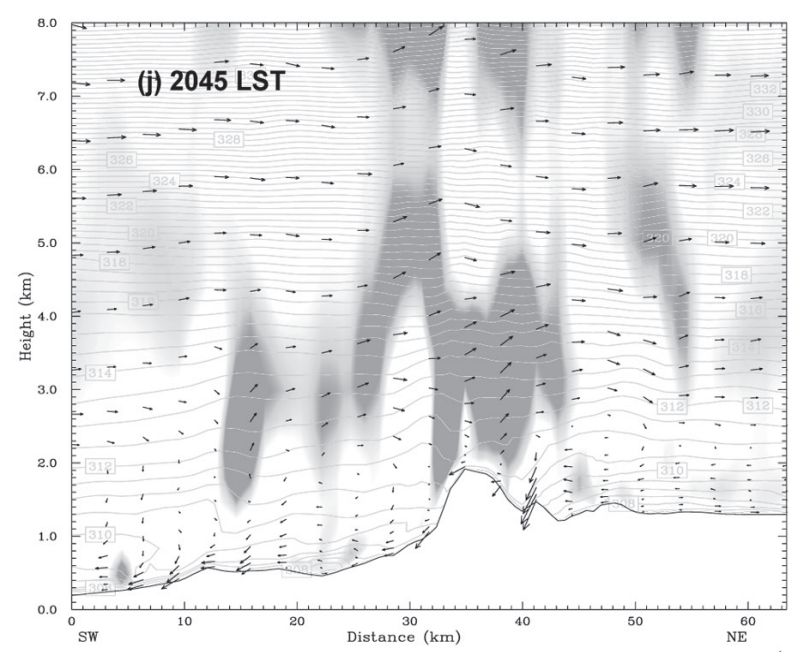

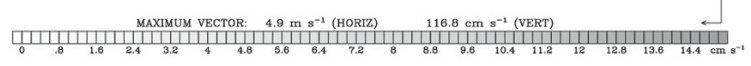



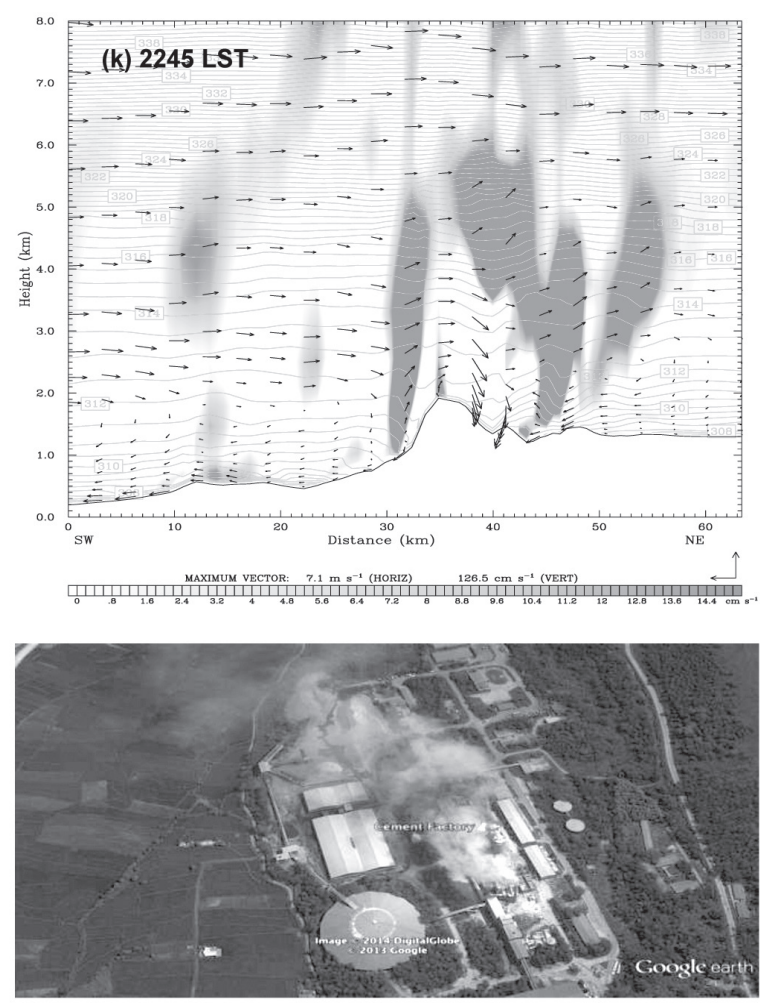

Fig. 4. Cross-sectional distributions of horizontal (vector), vertical (raster) and potential temperature (contours) along the southwest-northeast line passing through the center of the Hetauda Municipality and the Kathmandu valley (a-k) and the Nepal's largest cement factory, the Hetauda Cement Factory emitting huge amount of air pollutants that may intrude into the Kathmandu valley (l).

It is well known that the characteristic meteorological conditions and local wind systems play an important role in bringing in outside pollutants, stagnating over the area, as well as pumping up and flushing out the pollutants into other downwind areas. Depending on emissions and characteristic airshed transport phenomena, dirty air masses from urban/industrial centers containing various harmful pollutants can be transported many kilometers downwind. The local flow patterns over the finest calculation domain which covers the Hetauda and the Kathmandu valley (Fig.1 for bird-eye view of terrain, Fig. 2 for near surface local flows and Fig. 4 the crosssectional plots connecting the Hetauda and Kathmandu) strongly suggest that the pollutants released over the Hetauda valley and its associated areas can be effectively transported up into the Kathmandu valley. Indeed, the abrupt increase in the observed concentration of potential pollutants over the Kathmandu valley (Kitada \& Regmi, 2003) were actually attributed for the forest fire in the southern plain area a day earlier to the observation day.

\section{CONCLUSIONS}

The early monsoon time meteorological flow fields over the Hetauda and Kathmandu area have been studied with the application of Weather Research and Forecasting (WRF) Modeling System. The study reveals that local flows system over the Hetauda valley may develop in combination of valley and massive scale subsidence flows. Thus develop local flows effectively penetrates the Kathmandu valley as southwesterly and westerly local flows accompanied with plain-to-plateau winds and mountain wave excitations. Formation of rotor over the Hetauda valley area, excitation of mountain waves and downdrafts over the southwestern part of the Kathmandu valley can be hazardous to aviation activities. Over the Hetauda valley, immediate atmosphere is rather weakly stratified during the night and morning times as well and deep mixed layer of about $2500 \mathrm{~m}$ above the ground tends to develop regularly favoring efficient vertical dispersion of pollutants released in the Hetauda and its associated areas. However, thus dispersed pollutants may intrude into the Kathmandu valley along with the local flows. Air pollution control system for Kathmandu valley, thus, needs to take the emission over the Hetauda valley into its considerations. These preliminary findings, however, needs to be further supplemented with long-term studies in order to derive a definite conclusions on the aviation risk reduction and regional air pollution control.

\section{ACKNOWLEDGEMENTS}

This research was partially funded by University Grants Commission, Nepal. Authors are thankful to the Central Department of Physics, Tribhuvan University, Kirtipur for providing necessary research environment.

\section{REFERENCES}

Kitada T. and. Regmi, R. P. 2003. Air Pollution Distribution and Their Dynamics over the Kathmandu Valley, Nepal: As Revealed with Numerical Simulation and Observation. Journal of Applied Meteorology, American Meteorological Society 42(12): 17701798.

Regmi, R. P. and Maharjan, S. 2013. Wind Power Density over the Kathmandu Valley and its Surrounding Areas. Journal of Institute of Science and Technology 18(1): 43-49.

Regmi R. P., Kitada, T. and Kurata, G. 2003. Numerical Simulation of Late Wintertime Local Flows in the Kathmandu Valley, Nepal: Implication for Air Pollution Transport. Journal of Applied Meteorology, American Meteorological Society 42(3): 389-403.

Regmi, R. P. 2012. Study on spatial and temporal distribution of wind over the Hurhure Danda, Nawalparashi, Nepal: Implication for wind power generation.

Skamarock, W. C., Klemp, J. B., Dudhia, J., Gill, D. O., Barker, D. M., Wang, W., and Powers, J. G., 2005. A description of the advanced research WRF NCAR/ TN-468+STR, 88 pp. 